\title{
The sustainability-peace nexus in the context of global change
}

\author{
Hassan Virji ${ }^{1,2} \cdot$ Ayyoob Sharifi ${ }^{1,2} \cdot$ Shinji Kaneko ${ }^{1,2} \cdot$ Dahlia Simangan ${ }^{1,2}$
}

Published online: 10 October 2019

๑) Springer Japan KK, part of Springer Nature 2019

\section{Introduction}

The global challenge of sustainable development encompasses the complex interdependencies of environmental change, socio-economic development, and peaceful existence. Sustainability and peace are intricately linked, especially in the context of rapid global changes in the functioning of the Earth system. Peace and sustainable development in a fundamental sense are related to processes of globalization and socio-economic development. In fact, with the increasing trends of global change and geopolitical instability (IPCC 2018), there is a pressing need to deal with the potential interlinkages between sustainability and peace in the context of global change. We view peace as a broad and inclusive concept that goes beyond just the absence of war and conflict and pursues social harmony and justice (Galtung 1969). Structural and indirect forms of violence prevent amicable living conditions even in societies that are not subjected by conventional wars and armed conflicts. Within the context of sustainability-peace nexus, peace implies a broader concept that includes elements of individual inner peace, peaceful mindset, spirituality, peace cultures within organizations and regions, and peace with nature and other species. This holistic view of peace comprises negative peace-or the absence of armed conflict and direct violence-and positive peace, which entails the restoration of harmonious relationships and creation of social systems that address the underlying causes of all forms of conflict and violence (Galtung 1969). This notion of peace is central to

Ayyoob Sharifi

sharifi@hiroshima-u.ac.jp; sharifigeomatic@gmail.com

Hassan Virji

hvirji@start.org

1 Graduate School for International Development and Cooperation, Hiroshima University, Higashi Hiroshima, Japan

2 Network for Education and Research on Peace and Sustainability (NERPS), Hiroshima University, Higashi Hiroshima, Japan the Sustainable Development Goals (SDGs) (UN 2015). In fact, one implication of the deep interconnectivities of peace to all other SDGs is that if we do not address peace effectively, then we jeopardize all other goals.

Despite the significance of the sustainability-peace nexus, the existing knowledge on it is very limited. There is limited and fragmented scientific knowledge on potential implications and impacts of global, national, and local strategies and policies related to peace and security for sustainability (Brauch et al. 2016). Likewise, there is a lack of knowledge on measures for achieving the goal of sustainable peace especially under rapid environmental change. Policyand practice-relevant considerations on the linkages between "Sustainability Transition with Sustainable Peace" are even scarcer. In the past few years some preliminary works on this nexus have been conducted. For instance, the Handbook on Sustainability Transition and Sustainable Peace provides some basic knowledge on the sustainability-peace nexus (Brauch et al. 2016). However, existing research is mainly focused on the climate change-conflict nexus in conflictprone developing countries and fails to take account of the broader meaning of sustainability and peace. Achieving a better understanding of the complex and dynamic interactions between sustainability and peace warrants further research that also deals with major challenges for sustainable development and peace related to global change. These include, but are not limited to, climate change, state fragility, and digital transformation. Research on the sustainability-peace nexus to address these urgent and important challenges requires investigation of processes and relations between myriad sub-components of the nexus through transformative and transdisciplinary approaches that must engage a broad spectrum of stakeholders from the scientific, technology, policy, private and public sectors. Research on this nexus must also explicitly link to core natural science methodologies of integrated modeling and engage communities from natural and social sciences already involved in modeling the Earth System to develop and validate projections and predictions of future conditions that can inform development of policies and governance structures. 
Against this background, the proposed special issue will contribute to the evolution of sustainability science and advancing our understanding of the nexus by probing the complex and dynamic interactions between the human-natural earth system and providing better knowledge on how global changes affect our ability to attain sustainable development and peaceful coexistence. This will be achieved through inclusion of contributions from a diverse array of disciplines and stakeholder communities.

\section{Aims and scope of the special issue}

This Special Issue of Sustainability Science offers a platform for synthesizing existing knowledge and advancing our understanding of the sustainability-peace nexus in the context of global change. It aims to draw together a collection of high-quality papers, addressing uni- and bi-directional causal linkages between sustainability and peace, as well as, challenges and opportunities for promoting and sustaining peaceful environments that benefit humans as well as the nature. We encourage researchers and practitioners to submit original research articles, case studies, reviews, critical perspectives, and viewpoint articles on topics including, but not limited to, the following:

- the theoretical underpinnings of the sustainability-peace nexus,

- methodological aspects of studying the sustainabilitypeace nexus,

- transdisciplinary approaches and methods for studying the sustainability-peace nexus,

- case studies exploring the uni- and bi-directional causal linkages between sustainability and peace,

- causal relations between peace processes and the physical environment,

- the environmental component of post-conflict peacebuilding,

- the sustainability-peace nexus in international political negotiations and agreements,

- the sustainability-peace nexus in the context of major national and regional initiatives (e.g., the Belt and Road Initiative),

- integration of the sustainability-peace nexus in Education for Sustainable Development (ESD),

- the sustainability-peace nexus and efforts toward climate change adaptation and mitigation,

- climate change and migration,

- climate change and resource management,

- extreme events, resilience, and socio-economic and ecological security,

- disruptive social and technological innovations.

\section{Deadline, submission, and review process}

In addition to selected authors from "The Hiroshima Dialogue Forum on the Sustainability-Peace Nexus in the Context of Global Change", we invite interested authors to submit their titles and abstracts (about 250 words) to nerps@hiroshima-u. ac.jp by 31 January 2020. After receiving the invitation for a full-paper submission, authors should prepare their manuscripts following the Instructions for Authors. All manuscripts should be submitted directly via the journal's electronic editorial management system. Submitted manuscripts will be reviewed by at least two experts in the relevant field. Upon acceptance, the manuscripts will be published online after receipt of the corrected proofs.

- Manuscript submission deadline: May, 2020.

- Date of issue publication: May, 2021.

\section{Author guidelines}

https://www.springer.com/environment/environmental+manag ement/journal/11625?detailsPage=pltci_728046

\section{Submission guidelines}

For submission through EM system, please register in EM system (below link) and submit your article selecting the SI title. You can see the author tutorial on the right side of the registration page. Please, tag your submission with the SF tag "The sustainability-peace nexus in the context of global change".

https://www.editorialmanager.com/sust/mainpage.html.

\section{References}

Brauch HGN, Oswald U, Grin J, Scheffran JR (2016) Handbook on sustainability transition and sustainable peace. Springer, Switzerland

Galtung J (1969) Violence, peace, and peace research. J Peace Res 6(3):167-191

IPCC (2018) Global warming of $1.5^{\circ} \mathrm{C}$. An IPCC special report on the impacts of global warming of $1.5^{\circ} \mathrm{C}$ above pre-industrial levels and related global greenhouse gas emission pathways, in the context of strengthening the global response to the threat of climate change, sustainable development, and efforts to eradicate poverty [Masson-Delmotte, V., P. Zhai, H.-O. Pörtner, D. Roberts, J. Skea, P.R. Shukla, A. Pirani, W. Moufouma-Okia, C. Péan, R. Pidcock, S. Connors, J.B.R. Matthews, Y. Chen, X. Zhou, M.I. Gomis, E. Lonnoy, T. Maycock, M. Tignor, and T. Waterfield (eds.)]

UN (2015) Transforming our world: the 2030 agenda for sustainable development. Resolution adopted by the General Assembly on 25 September 2015. https://www.un.org/ga/search/view_doc. asp?symbol=A/RES/70/1\&Lang=E. Accessed 14 Aug 2019

Publisher's Note Springer Nature remains neutral with regard to jurisdictional claims in published maps and institutional affiliations. 